\section{Mental retardation}

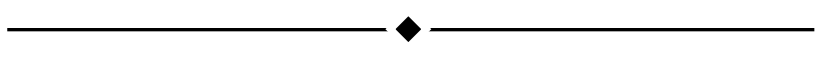

My congratulations for taking the initiative to approach the subject: the neurobiology of behavior and associated disorders.

I was very interested by the article on mental retardation by Vasconcelos. ${ }^{1}$ The article had an extensive bibliography, but, unfortunately it does not deal with Brazilian work. There is very good Brazilian work on this theme, such as that by our fellow pediatrician, the geneticist, Raquel Boy ${ }^{2}$ and the text written by Dr. Marcos José de Burle Aguiar, published in the book by Dr. Gerson Carakushansky ${ }^{3}$ (all from the clinical genetics department at SBP), in addition to the article by $\mathrm{Dr}$. Juan Llerena. ${ }^{4}$

It is difficult to write a synthesis on a subject as wide as mental retardation, but as a pediatrician I cannot omit to remind us that in our practice sequelae from neonatal asphyxia remain the greatest cause of mental retardation in Brazil. In countries that are little developed, such as ours, infectious diseases such as congenital cytomegalovirus 5 are another important cause of mental retardation, further to underdiagnosis, since serum testing for diagnosis is not performed routinely by the SUS (Brazilian National Health System) in Brazil. To witness these facts it is enough to work at any maternity unit in the country. These items were little discussed in the item on the causes of mental retardation, despite being cited in the epidemiology item.

I would have liked to have read about the epidemiology of mental retardation in Brazil and not in California, since the journal in which the article was published is Brazilian.

With respect of the genetic causes, our colleague performed an excellent review, but in the item on the neurobiology of mental retardation the text contains superficial commentaries that do not explain Figure 1 well.

In the item on the causes of mental retardation, I understand the author to mean to highlight exposure to teratogens ${ }^{6}$ during the prenatal period and not toxins as one cause, is this correct? Still on this item, we have emphasis given to cases of lead poisoning, pointing out that there are no reports of the prevalence of this cause in Brazil, which leads us to believe that this is not such an important cause as to merit prominence, whereas the use of teratogens is an important cause and was not highlighted, in common with the sequelae of prematurity and postnatal asphyxia by varying causes, such as pneumonia, meningitis, post-heart surgery, brain damage from sickle-cell anemia, untreated hypoglycemia, which are the most common causes for treatment in the routine of a pediatrician. ${ }^{3}$

Our colleague further cites a search run on the OMIM database returning 1,149 distinct syndromes having mental retardation $s$ one of their symptoms, but why cite neurofibromatosis (NFB I) in a list of less than 50 syndromes when there are so many others to cite if the majority of patients with neurofibromatosis do not have mental retardation? ${ }^{7}$

In the item on neurocutaneous disorders, I would like to know what executive dysfunction is. I further call attention to the classification by IQ, which is so debated and criticized, when there is a citation that $4-8 \%$ of the patients with NFB I have IQ $<70$ and attention deficit. Would this attention deficit not be being confused with mental retardation or reducing the IQ results of these children?

We know that in fragile $X$ syndrome the presence of FMR1 is more common than is FMR2, however, the author cites a study with a sample of 534 children (the disease has an incidence of $1: 2,500$ ) in which FMR1 was found in three cases and in which three additional cases of FMR2 were found. Is this incidence correct? In the database used and suggested by the author, Online Mendelian Inheritance in Man (http:// www3.ncbi.nlm.nih.gov/omim/) is the information that cases of FMR2 are rare.

In the item on how to investigate mental retardation, the author suggests that few metabolic diseases cause MR in isolation with no other associated symptoms and due to the prevalence of $0-5 \%$ in children with MR, metabolic investigation should not be included in initial screening, despite citing that there is consensus that initial evaluation should include a karyotype with 500 band resolution due to the $4-34.1 \%$ rate of frequency of chromosomal anomalies in patients with mental retardation.

I hope that this conduct does not enjoy the consensus of the society of pediatrics, since we live in a country where the Guthrie test is not performed for all children and, in our clinical practice there are children who could have had their mental retardation avoided if a laboratory test had been performed early but wasn't; not just for phenylcetonuria, but also for other treatable inborn errors of metabolism (IEM) and we could avoid such mental retardation. Inducing pediatricians to believed that IEM are rare is an error because, taken together they are common. Few pediatricians diagnose IEM cases, which may go more unnoticed than do chromosomopathy. 8

If IEM do not have mental retardation in isolation as a characteristic, in the majority of cases chromosomopathies also do not cause mental retardation in isolation, while the propedeutic for IEM diagnosis is cheaper and easier to obtain than a high-resolution karyotype in Brazil.

We should concern ourselves with not copying foreign models without valorizing the reality of those who care for patients with mental retardation in practice.

Concluding, I would have liked to have read a little on prognosis, since in the item on treatment we have avantgarde procedures without end while in the last paragraph there is a comment on the use of a drug for insomnia with 
adolescents with mental retardation, but there is no comment on whether it should be employed or if results were goodl.

I am grateful for the opportunity to discuss these subjects, which would not be possible if we did not have the Jornal de Pediatria, of such excellent quality.

\section{Erlane Marques Ribeiro}

MSc. Professor, Faculdade de Medicina de Juazeiro do Norte. Geneticist physician, Hospital Geral César Cals and Hospital Infantil Albert Sabin. E-mail: erlane@genecom.com.br

\section{References}

1. Vasconcelos MM. Retardo mental. J Pediatr (Rio J). 2004;80: S71-82.

2. Santos CB, Boy RT, Santos JM, Silva MPS, Pimentel MMG. Chromosomal investigations in patients with mental retardation and/or congenital malformations. Genet Mol Biol. 2000;23:703-7.

3. Aguiar MJB. A criança com deficiência mental. In: Carakushansky G. Doença Genética em Pediatria. 2a ed. Rio de Janeiro: Guanabara Koogan; 2001. p. 448-54.

4. Llerena Jr JC, Almeida JCC. Cytogenetic and molecular contributions to the study of mental retardation. Genet Mol Biol. $1998 ; 21: 273-9$.

5. Donato J, Ribeiro EM. Infecção congênita por citomegalovírus. Rev Bras Clin Terap. 2004;30:97-100.

6. Sanseverino MTV, Spritzer DT, Schuler-Faccini L. Manual de Teratogênese. Porto Alegre: Editora da UFRGS; 2001.

7. Viskochil D. Neurofibromatosis type 1. In: Cassidy SB, Allanson JE. Management of Genetic Syndromes. New York: Wiley-Liss; 2001. p. 229-51.

8. Giugliani R. Erros inatos do metabolismo: uma visão panorâmica. Pediatria Moderna. 1988;23:29-38.

\section{Author's reply}

We are grateful to Professor Erlane Marques Ribeiro for her interest in our recently published article on mental retardation (MR). ${ }^{1}$ We feel that we have a duty to clarify certain points emphasized by the professor:

- She claims that the bibliography does not contain Brazilian work. However, careful reading of the references will reveal that numbers 25, 40, 53 and 57 are by domestic authors. The study by Felix et al. (ref. 40) describes the etiology of a series of MR cases and was discussed on page S75.

- Professor Erlane did not like reading about the epidemiology of MR in California. We hope that she has read about the connection between folic acid deficiency and neural tube defects - despite the epidemiological data that document this association originating in Great Britain. ${ }^{2}$ We would also hope that the professor has read about sleeping position and the sudden infant death syndrome. Some of the principal studies that laid the foundations for the American Academy of Pediatrics' Back to Sleep campaign in 1994 came from New Zealand ${ }^{3}$ and Tasmania. ${ }^{4}$ We do not agree with a supposedly patriotic selection of which epidemiological studies are important. In our frank opinion, nationalism doesn't mix with science.
- She claims that the use of teratogens was not highlighted. However, the article contains an entire section and even an illustrative figure on fetal alcohol syndrome, which would appear to us to be the primary teratogen involved.

- In a review article on a subject as complex as MR, the criteria of prevalence should not be the only guide to authors' choices. The reason that we did not describe "in detail" cerebral palsy, meningitis, etc. within the causes of MR was our certainty that an informed reader of a supplement on "neurobiology of behavior" from the Jornal de Pediatria does not need to read a review article on MR to clarify diagnosis in such cases.

- On the contrary to the claim Doctor Erlane makes, at no point does the article mention, or induce the reader to believe, that inborn errors of metabolism (IEM) are rare. We maintain our position - which, since the pediatrics society did not sign the article, is only that of the author - that a "complete" investigation into IEM is inopportune during "initial" screening. We are in excellent company. ${ }^{5}$ Furthermore, our article proposed the rational and progressive selection of metabolic tests, as Table 2 ( $p$. S79 in the article) showed, and also emphasized the merits of anamnesis and physical examination to the investigation.

- We do not believe that, "it is enough to work at any maternity unit in the country" to better understand the causes of MR, since it is impossible to define a diagnosis of MR with certainty during the neonatal period. 5

- It is true that the intelligence quotient (IQ) test has been criticized, particularly in our country. We the exception of the reservations mentioned on page $\mathrm{S} 80$, our opinion is that it is very useful for evaluating children and adolescents with neuropsychiatric complaints. Not to mention the fact that the immense majority of scientific articles worldwide use an MR classification based on IQ scores.

- In our view, the article makes it very clear that mutations of the FMR1 gene are the most common cause of fragile $X$ syndrome. Furthermore, we believe that the article by Mazzocco et al., 6 while dealing with preliminary results, raises a clinically important question in dealing with the large group of preschool children with delayed language development. They did not find any complete FMR2 mutation, but found very small alleles of this gene in three children - which is itself an excellent research theme for geneticists.

- Doctor Erlane laments that SUS (Brazilian National Health Service) does not perform serum testing on neonates for congenital cytomegalovirus diagnosis. However, in contrast with what the professor suggests, the literature has established that serum tests do not help to define a diagnosis of congenital CMV infection and that, in the best of hypotheses, they merely exclude one. ${ }^{7}$ We hope for the day when SUS offers virus identification in urine or saliva culture or polymerase chain reaction to detect antigens.

- The section on the neurobiology of MR presents the principal current concepts on the subject, which can be gone into in more depth by means of reading, for example, reference number 22 . Figure 1 seemed to us to be selfexplanatory: an informed reader would know that it shows a neuron and the "actors" of synaptic transmission, many of which were named in the text. 
- The curiosity over what "executive dysfunction" might mean is welcomed. We recommend a consultation of the pertinent scientific literature.

- Professor Erlane and I agree on the requisite quality of the Jornal de Pediatria. This quality is also constructed by the interest and criticism of its readers.

\section{Marcio M. Vasconcelos}

MSc. Assistant professor, Universidade Federal Fluminense (UFF), Hospital Universitário Antônio Pedro, Rio de Janeiro, Brazil. Fellow in Pediatric Neurology, Children's Hospital, George Washington University, Washington, DC, USA.

\section{References}

1. Vasconcelos MM. Retardo Mental. J Pediatr (Rio J). 2004;80(2 Supl):S71-82.

2. Smithells RW, Sheppard S, Schorah CJ, Seller MJ, Nevin NC, Harris R, et al. Apparent prevention of neural tube defects by periconceptional vitamin supplementation. Arch Dis Child. 1981;56:911-18.

3. Mitchell EA, Scragg R, Stewart AW, Becroft DM, Taylor BJ, Ford RP, et al. Results of the first year of the New Zealand cot death study. N Z Med J. 1991;104:71-6.

4. Dwyer T, Ponsonby A-L, Newman NM, Gibbons LE. Prospective cohort study of prone sleeping position and sudden infant death syndrome. Lancet. 1991;337:1244-7.

5. Shevell M, Ashwal S, Donley D, Flint J, Gingold M, Hirtz D, et al. Practice parameter: evaluation of the child with global developmental de lay. Neurology. 2003;60:367-80.

6. Mazzocco MMM, Myers GF, Hamner JL, Panoscha R, Shapiro BK, Reiss AL. The prevalence of the FMR1 and FMR2 mutations among preschool children with language delay. J Pediatr. 1998; 132:795-801.

7. Stagno S. Cytomegalovirus. In: Behrman RE, Kliegman RM, Jenson HB, editors. Nelson Textbook of Pediatrics. 17th ed. Philadelphia: Saunders; 2004. p. 1068.

\section{Neonatal networks}

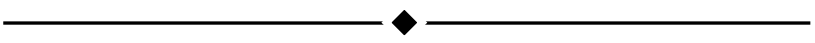

Dear Editor,

It was with great interest that we read the article published in the July/August 2004 issue on the neonatal use of corticosteroids. ${ }^{1}$ In the editorial that accompanied this article, ${ }^{2}$ it was mentioned that "...the use of antenatal corticosteroid therapy in preterm labor at less than 34 weeks reached $61 \%$. As far as we know, this figure is much higher than in any other Latin American study," and, in addition to the BNRN, the Vermont-Oxford and NICHD were cited as examples of "multicentric networks".

There was, however, an omission in the form of the noninclusion of the NEOCOSUR Collaborative Group, a neonatal network whose goal is to collect information, prospectively, on newborn babies weighing less than $1,500 \mathrm{~g}$ and their mothers. The network is made up of 16 neonatal units from five South-American countries (Argentina, Chile, Peru, Paraguay and Uruguay) and has accumulated data on, since 1997 , a total of 3,812 preterms weighing less than $1,500 \mathrm{~g}$ at birth. We publish in scientific journals ${ }^{3}$ and have given several presentations at a variety of scientific meetings, Pediatric Academic Societies (PAS), Latin-American Pediatric Research Society (SLAIP - Sociedade Latino-americana de Pesquisa Pediátrica), Argentinean Society of Pediatrics National Research Meetings (Encuentro Nacional de Investigación Pediátrica) and the Chilean Pediatric and Neonatology congresses (Congreso Chileno de Pediatría and the Congreso Chileno de Neonatología).

The neonatal corticoid usage recorded on the NEOCOSUR database is, currently, $68.9 \%(51-100)$, greater than that reported in Montevideo, Uruguay, ${ }^{4}$ and of the study in question. ${ }^{1}$ These data confirm that, in our countries, the application of preventative measures, the effectiveness of which has already been proven in clinical trials, has spread to localized populations, even though we do still need to fight unceasingly to increase their use.

\section{Carlos Grandi}

PhD. Researcher, Perinatal Epidemiology and Biostatistics, Maternidade Sardá, Buenos Aires, Argentina. E-mail: cgrandi@intramed.net

\section{José Ceriani Cernadas}

Chief of the Department of Pediatrics, Hospital Italiano, Buenos Aires, Argentina. E-mail: jceriani@hitalba.edu.ar

\section{References}

1. Rede Brasileira de Pesquisas Neonatais. Uso antenatal de corticoesteróide e evolução clínica de recém-nascidos prétermo. J Pediatr (Rio J). 2004;80:277-84

2. Barros F, Díaz-Rosello J. Redes multicêntricas e a qualidade de atenção neonatal. J Pediatr (Rio J). 2004;80:254-6.

3. Grupo Colaborativo Neocosur. Very-low-birth-weight infant outcomes in 11 South American NICUs. J Perinatol. 2002;22:2-7.

4. Matijasevich A, Barros F, Forteza C, Diaz-Rosello J. Atenção à saúde de crianças de muito baixo peso ao nascer de Montevidéu, Uruguay: comparação entre os setores públicos e privado. J Pediatr (Rio J). 2001:77:313-20.

\section{Authors' reply}

Dear Editor,

We are grateful for the opportunity to reply to the letter from our colleagues Drs. Grandi and Ceriani Cernadas, from Buenos Aires. Initially we would like to say that, in our Editorial, we used the Vermont-Oxford Network and the North-American NICHD networks as being the best known, and that it was not our intention to cite all existing networks. The fact that the NEOCOSUR network was not included should not, therefore, be seen as an omission. 